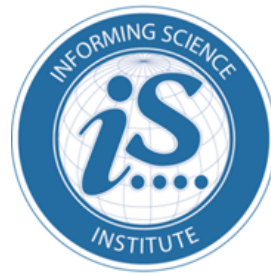

Proceedings of the Informing Science + Information Technology Education Conference

An Official Publication

of the Informing Science Institute

InformingScience.org

InformingScience.org/Publications

July 31 - August 5 2017, Ho Chi Minh City (Saigon), Vietnam

\title{
The EMERgent Global Marketing Challenges FOR Kerala CARDAMOM PRODUCERS VIS-À-VIS THE ROLE OF THE SPICES BOARD OF INDIA [ABSTRACT]
}

\begin{abstract}
Majo George* RMIT International university, Vietnam
Elsa Cherian

Centre for Management studies, North Eastern Regional Institute of Science and Technology, Itanagar, Arunachal Pradesh, India

*Corresponding Author
\end{abstract}

Majo.george@rmit.edu.vn

Elsacherian13@gmail.com

\begin{abstract}
Aim/Purpose

Since the late 1980s the Indian monopoly on the export of Cardamom has suffered a sharp and devastating setback from which India cannot recover. The research is looking into the reasons and suggests remedies.

Background

The main problems are the competition from Guatemala, higher production costs, an increasing domestic demand, the lack of action from the Spices Board of India

Methodology

The methodology used was not the conventional one, with an aim to obtain truthful and unbiased responses from all those involved using a mixture of all available methods.

Contribution

The paper focuses on the provocations, limitations and seriousness of the situation and highlights the facts and figures to make the plantation sector to regain its prosperity.

Findings Lack of awareness among the farmers about the latest farming and post harvesting technologies and marketing strategies.

Recommendations This paper suggests measures to be taken by the cardamom farmers and the for Practitioners market intermediaries, and analyses the future role of the Spices Board of India

Recommendation for Researchers Further detailed studies are needed to ascertain current market share of the main competitors, to reduce the cost of production

Impact on Society If the findings in this paper are followed, the Indian Cardamom industry could retain its previous position in the market

Future Research Studies can be done export market, the use technology and export.

Keywords cardamom, global marketing, Guatemala threat, Spices Board of India, export market
\end{abstract}

The final version of this paper will be published in the International Journal of Community Development and Management Studies and this link will be replaced with a link to that paper.

(CC BY-NC 4.0) This article is licensed to you under a Creative Commons Attribution-NonCommercial 4.0 International License. When you copy and redistribute this paper in full or in part, you need to provide proper attribution to it to ensure that others can later locate this work (and to ensure that others do not accuse you of plagiarism). You may (and we encourage you to) adapt, remix, transform, and build upon the material for any non-commercial purposes. This license does not permit you to use this material for commercial purposes. 


\section{BIOGRAPHIES}

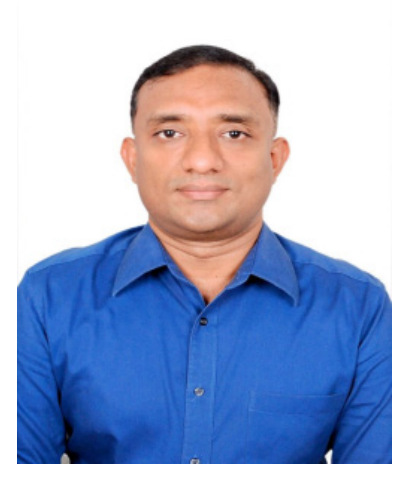

Mr. Majo George MBA., M.Com., M.Phil., is a Lecturer at RMIT International University, Vietnam. Mr. Majo has wide range of experience in industry and academic fields in the South East Asia region and is keen to do research in Marketing, Management, and international Business.

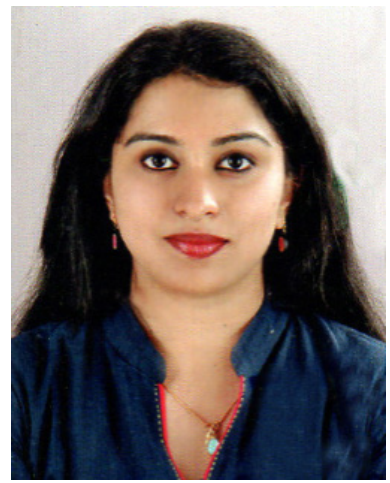

Mrs. Elsa Cherian MBA is working as Assistant Professor at the Centre for Management Studies, North Eastern Regional Institute of Science and Technology, Arunachal Pradesh, India. She is interested in proceeding her research in Marketing and International Business. 